\title{
Primary lipodystrophy
}

INSERM

\section{Source}

INSERM. (1999). Orphanet: an online rare disease and orphan drug data base. Primary

lipodystrophy. ORPHA:90970

Primary lipodystrophies represent a heterogeneous group of very rare diseases

characterized by a generalized or localized loss of body fat (lipoatrophy). 